\title{
DEVELOPMENT OF A SIMULATION MODULE FOR THE PROCESS OF ALCOHOLIC FERMENTATION USING A FREE SOFTWARE
}

\author{
Hugo Magalhães da Fonseca ${ }^{1}$, Anamaria de Oliveira Cardoso ${ }^{2}$ \\ ${ }^{1}$ Universidade Federal dos Vales do Jequitinhonha e Mucuri, Diamantina, Brasil. \\ E-mail: hugomagalhaesfsk@gmail.com \\ ${ }^{2}$ Universidade Federal dos Vales do Jequitinhonha e Mucuri, Diamantina, Brasil. \\ Recebido em: 06/04/2019 - Aprovado em: 10/06/2019 - Publicado em: 30/06/2019 \\ DOI: 10.18677/EnciBio_2019A176
}

\begin{abstract}
This work has proposed the development of a simulation module for the alcoholic fermentation process, from the integration of two free software: COCO Simulator and Scilab. A single-stage continuous fermenter was modeled from practical conditions of fermentation processes for the production of ethanol. It was fed with a solution containing $20.2 \%$ (mass/mass) of glucose and produced a wine with concentration equal to $54.85 \mathrm{~kg} \cdot \mathrm{m}^{-3}$ of ethanol. The model used in the simulation demonstrated fidelity to the expected behavior. It took in consideration the common inhibiting agents: product, substrate and operating temperature. The fermenter achieved a conversion $47 \%$ below ideal due to exposure of cells to high ethanol levels. Inhibition by substrate exhibited a linear profile, becoming more severe as the concentration of glucose in the feed increased. The increase in temperature was unfavorable to the conversion of sugar into alcohol, and its effects aggravated above $30 \stackrel{\circ}{ } \mathrm{C}$. The results obtained indicate success of the initiative, that aims to contribute to the strengthening and evolution of the industry.
\end{abstract}

KEYWORDS: ethanol, fermentation, simulation

\section{DESENVOLVIMENTO DE MÓDULO DE SIMULAÇÃO PARA PROCESSO DE FERMENTAÇÃO ALCOÓLICA EM SOFTWARE LIVRE}

\section{RESUMO}

Este trabalho propôs o desenvolvimento de um módulo de simulação para o processo de fermentação alcoólica, a partir da integração de dois softwares livres e gratuitos: COCO Simulator e Scilab. A partir de uma modelagem inspirada em processos práticos de fermentação para a produção e etanol, um fermentador contínuo de único estágio, foi alimentado com uma solução contendo $20,2 \%$ de glicose produzindo um vinho de concentração igual a $54,85 \mathrm{~kg} \cdot \mathrm{m}^{-3}$ de etanol. $\mathrm{O}$ modelo utilizado na simulação mostrou fidelidade ao comportamento esperado frente aos agentes inibidores comuns como produto, substrato e temperatura de operação. A exposição a altos níveis de etanol, devido ao uso de apenas um fermentador forneceu uma conversão $47 \%$ abaixo do ideal. A inibição por substrato apresentou um perfil linear, tornando-se mais severo à medida que a concentração de glicose na alimentação aumentou. $\mathrm{O}$ aumento da temperatura mostrou-se prejudicial à conversão de açúcar em álcool, sendo os seus efeitos agravados a partir dos $30^{\circ} \mathrm{C}$. Os resultados obtidos apontam para o sucesso da iniciativa que visa contribuir para o fortalecimento e evolução da indústria.

PALAVRAS-CHAVE: etanol, fermentação, simulação 


\section{INTRODUCTION}

The current highly competitive industrial environment demands the combination of new technologies for the modernization of manufacturing processes. This modern convergence of technologies is often called "fourth industrial revolution" and promises to change the way we live, as it happened in the past (MAYNARD, 2015).

Several countries present initiatives that aim at the development and implementation of advanced manufacturing processes. This is the case of the strategic plans "Made in China 2025" presented by the Chinese government (CHINA, 2015), "Strategy for American leadership in advanced manufacturing" presented by de United States (OSTP, 2018) and the German initiative "Industrie 4.0" (HENNING, 2013).

The concept of the advanced manufacturing process is not new. However, it continually changes by means of the development and application of new technologies. Today, an advanced production structure relies on the integrated use of CPS (Cyber-Physical Systems) and loT (Internet of Things) technologies. These are considered the driving forces of the fourth industrial revolution. CPS and IoT coexist in the industrial environment to give rise to a mechatronic system of intelligent, self-conscious production capable of making important decisions along the entire production chain and promoting deep human-machine interaction (JESCHKE et al., 2017).

This modern production model aims to provide companies with more agility to respond to market changes through a dynamic allocation of resources and flexible manufacturing. Also, it aims at high level of efficiency from the optimization of manufacturing, management and marketing operations. Environmental sustainability through the sensible use of natural resources and reduction of pollutant emissions. And finally, security, by means of inherently safer design of processes, fault diagnostics with autonomous correction, as well as robust data protection (QIAN et al., 2017).

A fundamental element for the development of advanced processes is the computational simulation. It is considered one of the pillars of industry 4.0 and an essential part of CPS. The simulation of processes, products and materials will raise data for the creation of realistic virtual models, commonly called "Digital Twins" (ROSEN et al., 2015). These models will provide the operators with the possibility of conducting evaluations on a mathematical model loyal to reality, in contrast to conducting experimental tests in the operational unit. This will reduce setup time, cost and improve the quality of processes and products (RÜBMANN et al., 2015).

Every sector of the industry tends to enhance themselves with its current phase of transformation. Currently, much attention is being given to the biofuels sector, predominantly due to the negative impacts that a possible reduction of the oil supply would cause in the global economy. In addition, biofuels have sustainable and environmentally friendly characteristics (CHENG, 2017). Thus, it is of great interest to society the development of the sector.

Among the biofuels available today, ethanol occupies a prominent position. With $85 \%$ of its production concentrated in the United States and Brazil, ethanol is the most used biofuel in the transportation sector. It is mostly produced through fermentation process (AZHAR et al., 2017). Several countries, such as the USA, Brazil, China and Canada, have pledged to encourage the use of ethanol as an alternative to petroleum (ZABED et al., 2017). This will contribute to increase by $14 \%$ 
the world production of bioethanol by 2026, reaching a total of approximately 623 billion liters per year (FAO, 2016).

Considering the significance of ethanol to the world scenario and the potential for development made possible by the application of technologies based on the new industrial revolution, this article proposes the development of a simulation module of the ethanol fermentation process, through the integrated use of free software COCO Simulator and Scilab. This work is seen as a contribution to the development of Digital Twins using free software, characterizing a relevant step in the direction of a 4.0 fermentative process.

\section{MATERIAL AND METHODS}

COCO (CAPE-OPEN to CAPE-OPEN) COCO is a free chemical process simulation environment, that uses CAPE-OPEN protocol (Computer-Aided Process Engineering in Open Interfaces). This protocol allows unit operations and thermodynamic models to share a common interface, compatible with most of the simulation environments available in the market (BATEN ; PONS, 2014).

Scilab is an open source, free-of-charge software for numerical computing applied to science and engineering. This software is virtuous for performing numerical analysis, data visualization, algorithm development and modeling, among others. It presents great versatility due to a series of functionalities and capacity of intercommunication with other software (SCILAB, 2018).

The simulations were performed using the COCO Simulator software. Primarily, the property calculation model was defined, in this case the NRTL. The components used in the simulation were water, ethanol, glucose and biomass. The first two compounds are already in the database. However, glucose and biomass were not. Thus, they had to be created, and their properties were inserted in the software according to literature data (WOOLEY ; PUTSCHE, 1996) (FIGURE 1).

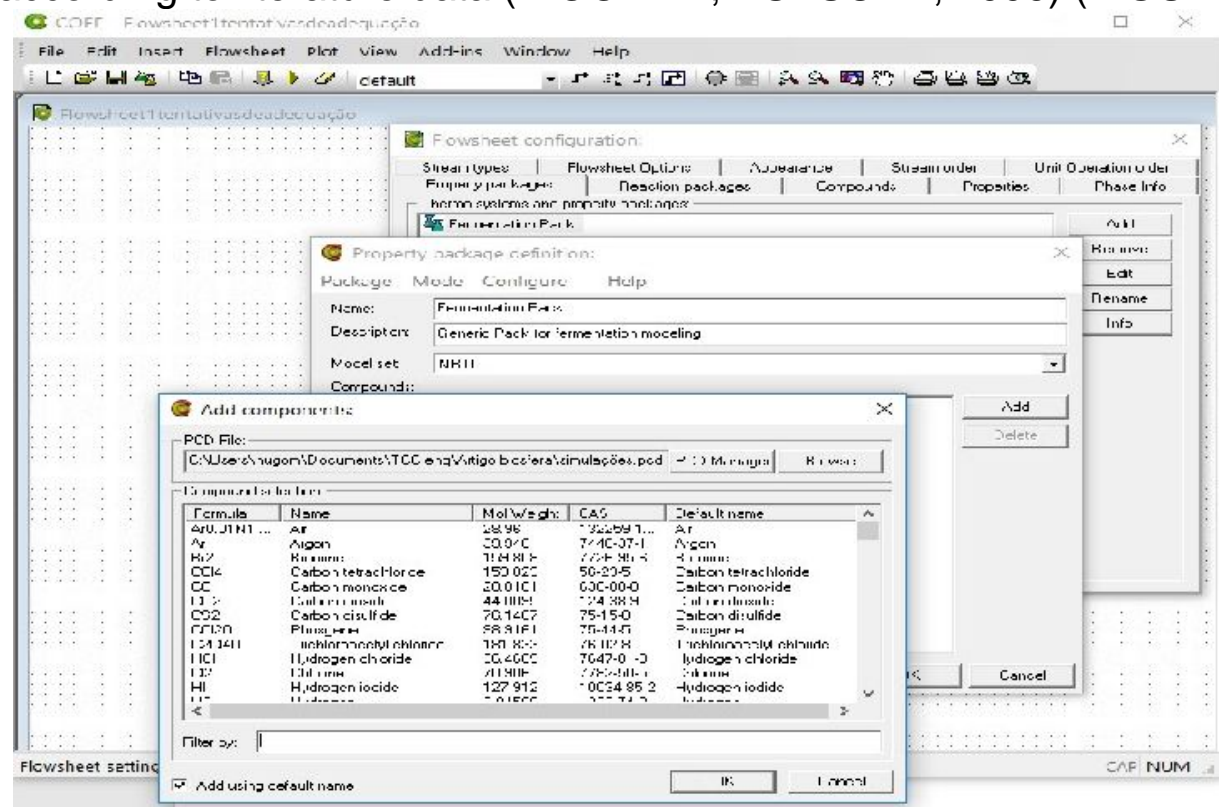

FIGURE 1. Selection of the thermodynamic package and inclusion of the components used in the simulation. Source: Own collection.

COCO does not hold the option of fermentation in its package of unit operations. In another hand, it allows the insertion of new unit operation models. In this way, the plug-in of Scilab's unit operation was inserted in the simulation 
environment of $\mathrm{COCO}$ to model the process of alcoholic fermentation from glucose (FIGURE 2).

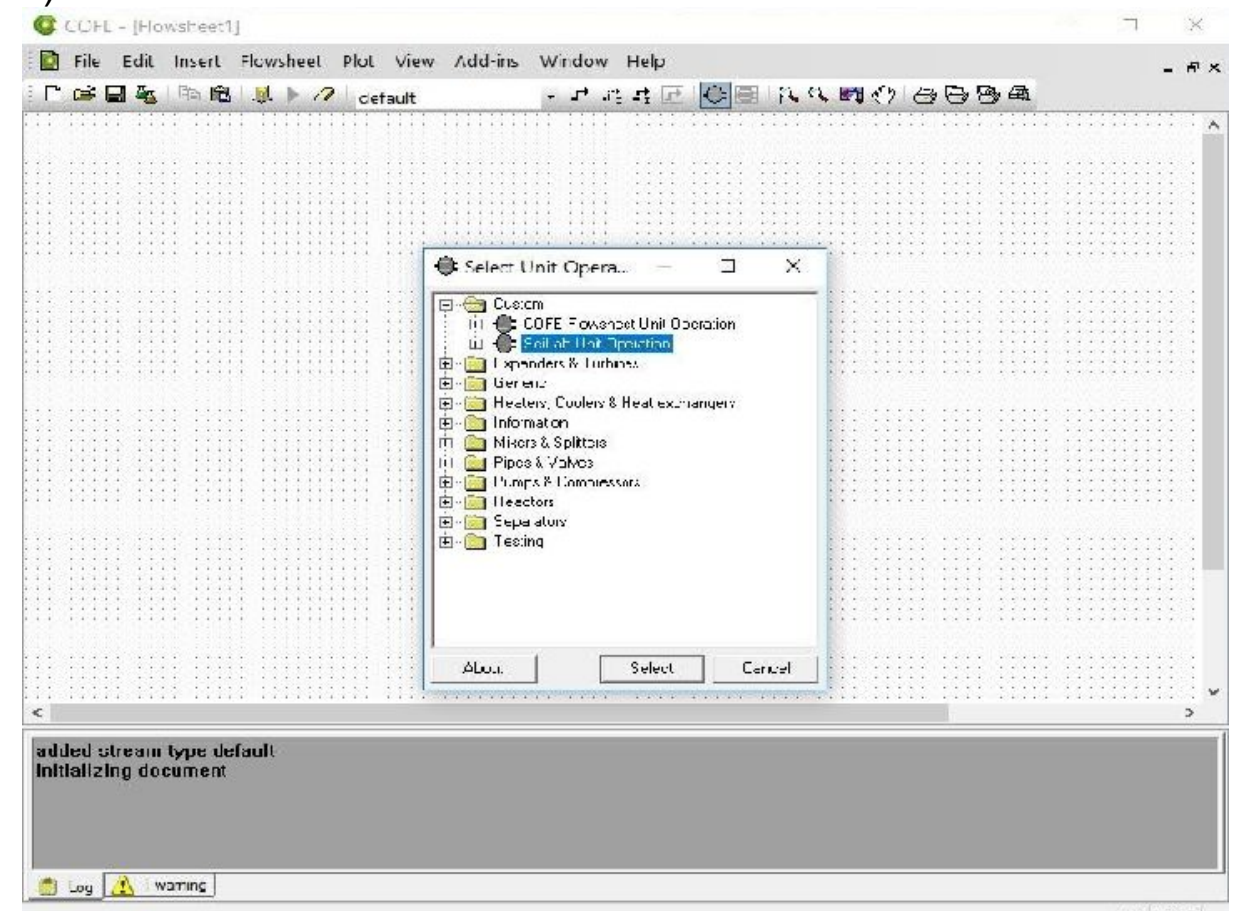

FIGURA 2. Selection of Scilab unit operation module in the COCO simulation environment. Source: Own collection.

In the edition option of the Scilab unit operation (FIGURE 3), the input and output ports, parameter input and the code containing the model of a steady state continuous fermentation system were inserted.

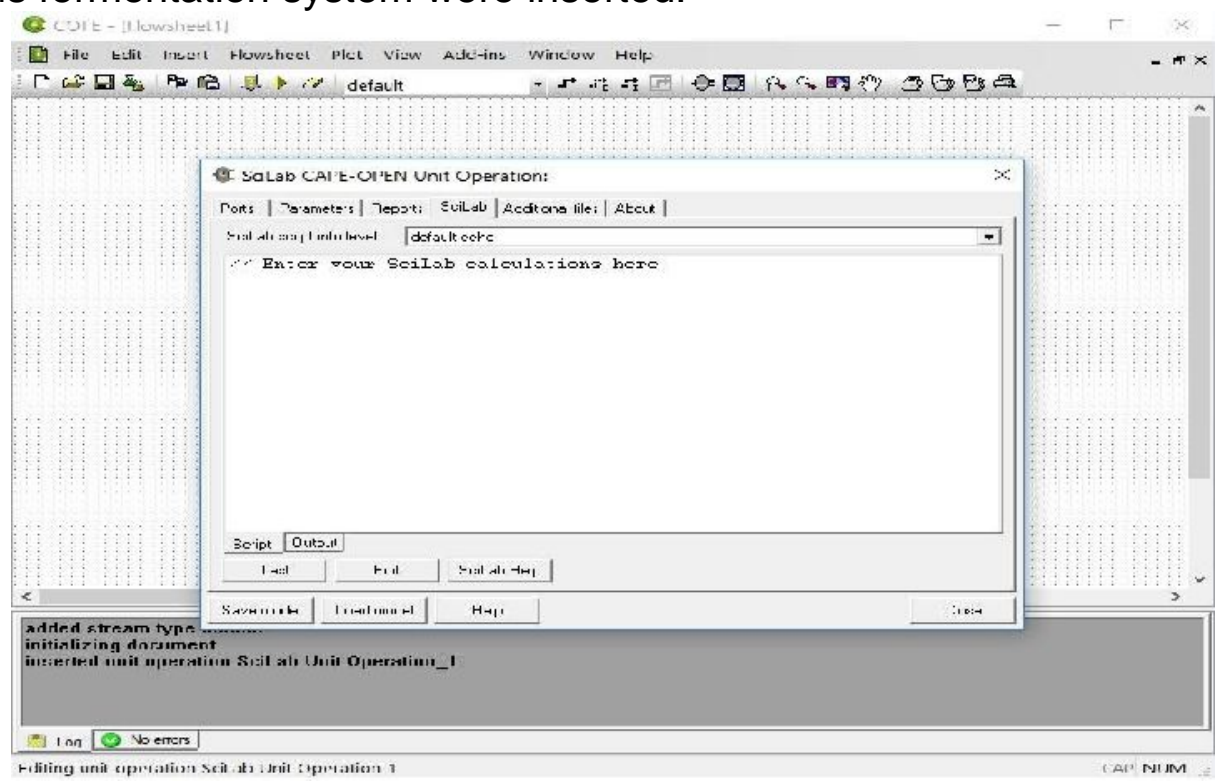

FIGURE 3. Editing environment for the Scilab unit operation. Source: Own collection.

The mass balance of the model assumes isothermal operation condition, constant density for all liquid streams and perfect mixing. The rate law of the reaction used in this balance was the one proposed by Lee et al. (1983). The parameters values of these equations, shown in Table (1), were those proposed and validated by Andrietta and Maugeri (1994). 
TABLE 1 - Fermentation parameters used in the model.

\begin{tabular}{cc}
\hline Parameter & Value \\
\hline $\mathrm{k}_{\mathrm{d}}\left(\mathrm{h}^{-1}\right)$ & 0.0083 \\
\hline $\mathrm{K}_{\mathrm{s}}\left(\mathrm{h}^{-1}\right)$ & 0.48 \\
\hline $\mathrm{K}_{\mathrm{i}}\left(\mathrm{kg} / \mathrm{m}^{3}\right)$ & 203.5 \\
\hline $\mathrm{C}_{\mathrm{P}}^{*}\left(\mathrm{~kg} / \mathrm{m}^{3}\right)$ & 90.0 \\
\hline $\mathrm{Y}_{\mathrm{X} / \mathrm{S}}\left(\mathrm{kg}_{\text {cell }} / \mathrm{kg}_{\text {substrate }}\right)$ & 0.035 \\
\hline $\mathrm{P}_{\mathrm{P} / \mathrm{S}}\left(\mathrm{kg}_{\text {product }} / \mathrm{kg}_{\text {substrate }}\right)$ & 0.48 \\
\hline
\end{tabular}

The model of Lee et al. was chosen because it considers the effects of inhibition by the concentration of product, substrate and cells on the reaction rate. This model also had its fidelity evaluated under typical industry operating conditions. The mass balance, as well as the equations of the kinetic model of Lee et al. (1983), are shown in Equations (1) to (6).

Global mass balance:

$$
\rho \frac{d V}{d t}=\rho\left(F^{i n}-F^{\text {out }}\right)
$$

where $\rho$ stands for density $\left(\mathrm{kg} \cdot \mathrm{m}^{-3}\right), V$ is the fermenter volume $\left(\mathrm{m}^{3}\right), F^{\text {in }}$ the inlet volumetric flow rate $\left(\mathrm{kg} \cdot \mathrm{m}^{-3}\right), F^{\text {out }}$ the outlet volumetric flow rate $\left(\mathrm{kg} \cdot \mathrm{m}^{-3}\right)$ and $t$ means time (h).

Mass balance for the i-th component:

$$
\frac{d C_{i}}{d t}=\frac{F^{i n}}{V}\left(C_{i}^{i n}-C_{i}\right)+r_{i}
$$

where $c_{i}$ represents the i-th component concentration $\left(\mathrm{kg} \cdot \mathrm{m}^{-3}\right), c_{i}^{i n}$ the concentration of the $\mathrm{i}$-th component in the inlet $\left(\mathrm{kg} \cdot \mathrm{m}^{-3}\right), r_{i}$ the reaction rate of the $\mathrm{i}$-th component $\left(\mathrm{kg} \cdot \mathrm{m}^{-3} \cdot \mathrm{h}^{-1}\right)$.

Cell reaction rate:

$$
r_{X}=\mu C_{X}
$$

where $r_{X}$ is the cell reaction rate $\left(\mathrm{kg} \cdot \mathrm{m}^{-3} \cdot \mathrm{h}^{-1}\right), \mu$ the specific growth rate of cells $\left(\mathrm{h}^{-1}\right)$ and $c_{X}$ the concentration of cells $\left(\mathrm{kg} \cdot \mathrm{m}^{-3}\right)$.

Glucose reaction rate:

$$
r_{S}=\mu C_{X} \frac{1}{Y_{X / S}}
$$

where $r_{S}$ is the reaction rate of the substrate $\left(\mathrm{kg} \cdot \mathrm{m}^{-3} \cdot \mathrm{h}^{-1}\right)$ and $Y_{X / S}$ the coefficient of cellular production ( $\mathrm{kg}_{\text {cell }} \cdot \mathrm{kg}^{-1}$ substrate).

Ethanol reaction rate: 


$$
r_{p}=\mu C_{X} \frac{Y_{P / S}}{Y_{X / S}}
$$

where $r_{p}$ represents the ethanol reaction rate $\left(\mathrm{kg} \cdot \mathrm{m}^{-3} \cdot \mathrm{h}^{-1}\right)$ and $Y_{P / S}$ the coefficient of ethanol production ( $\mathrm{kg}_{\text {cell }} \cdot \mathrm{kg}^{-1}$ product $)$.

Kinetic model of Lee et al.:

$$
\mu=\mu_{\max }\left(\frac{C_{S}}{k_{S}+C_{S}}\right)\left(1-\frac{C_{p}}{C_{p}^{*}}\right)^{n}\left(1-\frac{C_{X}}{C_{X}^{*}}\right)^{m}
$$

where $\mu_{\max }$ represents the maximum specific growth rate $\left(\mathrm{h}^{-1}\right), k_{s}$ the half-velocity constant $\left(\mathrm{kg}^{-3}\right), c_{s}$ the substrate concentration $\left(\mathrm{kg} \cdot \mathrm{m}^{-3}\right), c_{p}$ is the ethanol concentration $\left(\mathrm{kg} \cdot \mathrm{m}^{-3}\right), C_{D}^{*}$ the concentration of inhibition by product $\left(\mathrm{kg} \cdot \mathrm{m}^{-3}\right)$ and $C_{X}^{*}$ the concentration of inhibition by cells $\left(\mathrm{kg} \cdot \mathrm{m}^{-3}\right)$.

The present model also considers the effects caused by the operating temperature on the cell growth rate and on the cell tolerance to the product accumulation. Dale et al. (1990) demonstrate in their work that the effects of temperature on the maximum growth rate of Saccharomyces cerevisiae can be described by the Arrhenius equation:

$$
\mu_{\max }=A e^{\left(-\frac{E}{R T}\right)}
$$

where $A$ is the adjustment constant, $E$ the activation energy $\left(\right.$ cal.mol $\left.{ }^{-1}\right), R$ the ideal gas constant (cal.mol $\left.{ }^{-1} \cdot \mathrm{K}^{-1}\right)$ and $T$ represents the temperature $(\mathrm{K})$.

Van Uden (1985) proposed in his work that the effects of temperature on the concentration of inhibition by product present the following behavior:

$$
P_{\max }=K_{0} e^{(a T)}
$$

where $K_{0}$ and a are empirical constants.

The values of the constants used in Equations (7) and (8) were those defined by Andrietta \& Maugeri (1994) for an operating temperature of $32 \stackrel{\circ}{\circ}$. For this, the authors performed small-scale tests and promoted adjustments to obtain compatibility with data found for S. Cerevisiae.

TABLE 2 - Kinect parameters for Equations (7) and (8).

\begin{tabular}{cc}
\hline Parameter & Value \\
\hline $\mathrm{A}$ & $4,50 \times 10^{10}$ \\
$\mathrm{E}\left(\mathrm{cal} \cdot \mathrm{mol}^{-1}\right)$ & $1,54 \times 10^{4}$ \\
\hline $\mathrm{R}\left(\mathrm{cal} \cdot \mathrm{mol}^{-1} \cdot \mathrm{K}^{-1}\right)$ & 1,986 \\
\hline$K_{0}\left(\mathrm{~kg} \cdot \mathrm{m}^{-3}\right)$ & 895,6 \\
\hline $\mathrm{A}\left({ }^{\circ} \mathrm{C}^{-1}\right)$ & $-0,0676$ \\
\hline
\end{tabular}


The fermenter volume is estimated from the optimum retention time for a single-stage fermenter of 42.5 hours as determined by Ghose and Tyagi (1979) and the user-defined flow. In this case, a feed rate, substrate concentration, recycle of cells and product compatible with industrial data were used, in accordance with the work of Fonseca et al. (2016). The cell recycle was considered in the Scilab modeling code. However, it is not demonstrated in the simulation environment of COCO Simulator. These values and the other operational parameters are shown in Table (3).

TABLE 3 - Feed stream operational parameters.

\begin{tabular}{cc}
\hline Parameter & Value \\
\hline$F^{\text {in }}\left(\mathrm{m}^{3} \cdot \mathrm{h}^{-1}\right)$ & 687 \\
\hline$C_{X}^{i n}\left(\mathrm{~kg} \cdot \mathrm{m}^{-3}\right)$ & 90 \\
\hline$C_{S}^{\text {in }}\left(\mathrm{kg} \cdot \mathrm{m}^{-3}\right)$ & 202 \\
\hline$C_{P}^{\text {in }}\left(\mathrm{kg} \cdot \mathrm{m}^{-3}\right)$ & - \\
\hline
\end{tabular}

Once all the necessary parameters were defined, a primary simulation was performed to evaluate the suitability of the model to industrial processes reported in the literature. Subsequently, substrate concentrations in the feed were varied between 15 and $25 \%$ (\% mass/mass) at a constant temperature of $32{ }^{\circ} \mathrm{C}$. This was done to evaluate the effects of feed substrate concentration on the conversion of sugars into ethanol in the fermenter. Then the operating temperature was varied between 20 and $40{ }^{\circ} \mathrm{C}$ at a constant glucose concentration in the feed of $20.2 \%$. This aimed to evaluate the effects of temperature on the conversion of sugars into ethanol.

\section{RESULTS AND DISCUSSION}

The mass balance model was solved with the use of the "ode" function of Scilab, from the initial conditions previously defined. Figure 4 shows the fermentation process in the COCO simulation environment, along with a report of streams and the fermenter that demonstrate the results obtained.

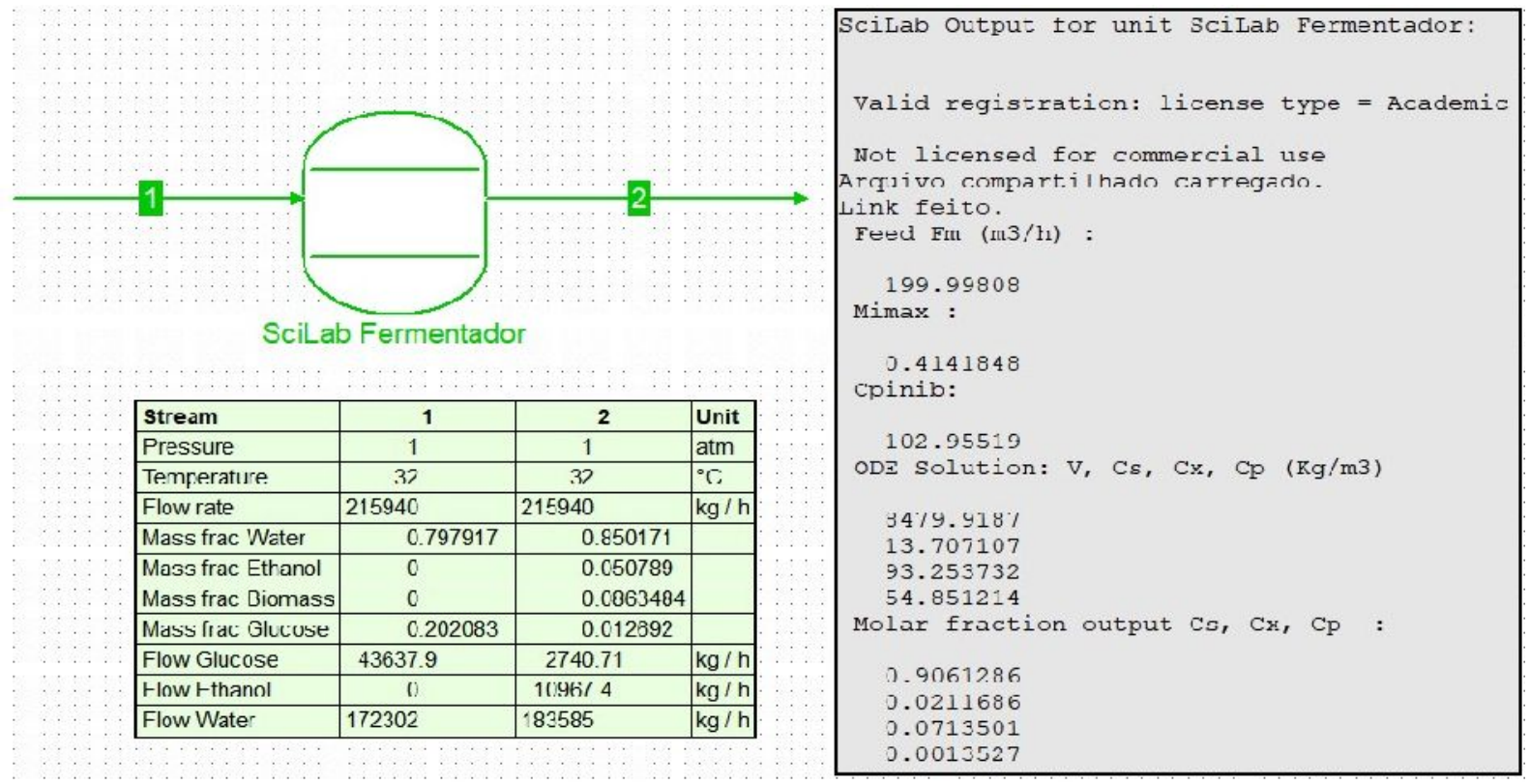

FIGURE 4 - Simulation environment of COCO Simulator along with the fermentation system solved. Source: own collection. 
From the defined conditions, the fermentation system with feed stream of approximately $200 \mathrm{~m}^{3}$ containing $20,2 \%$ of glucose, operating at $32{ }^{\circ} \mathrm{C}$, produced a wine containing $54,85 \mathrm{Kg} / \mathrm{m}^{3}$ of ethanol. This concentration is in accordance with the results obtained by Taylor et al. (1995) for a simple continuous fermenter, and close to the $63 \mathrm{Kg} / \mathrm{m}^{3}$ obtained by Kida et al. (1989). The mass fraction of ethanol in the wine was 5,08\%. It is close to the result obtained by Palacios-Bereche et al. (2015), of approximately $6 \%$. However, the conversion of glucose into ethanol obtained was 0.27 . This value represents $53 \%$ of the theoretical maximum value of 0,51 predicted by the stoichiometry of the conversion reaction of glucose into ethanol. This result can be attributed to inhibition of cell growth by product accumulation. This effect can be minimized by the use of reactors in series, which allows part of the fermentation to occur at lower concentrations of ethanol (LEE et al., 1985).

The following simulations aimed to evaluate the effects of the substrate concentration on the conversion of sugar into ethanol in the microbiological reactor. The "Parametric Study" function of COCO Simulator was then used to vary the concentration of glucose in the feed between 15 and $25 \%$ at a constant temperature of $32^{\circ} \mathrm{C}$. The results are demonstrated in Figure 5.

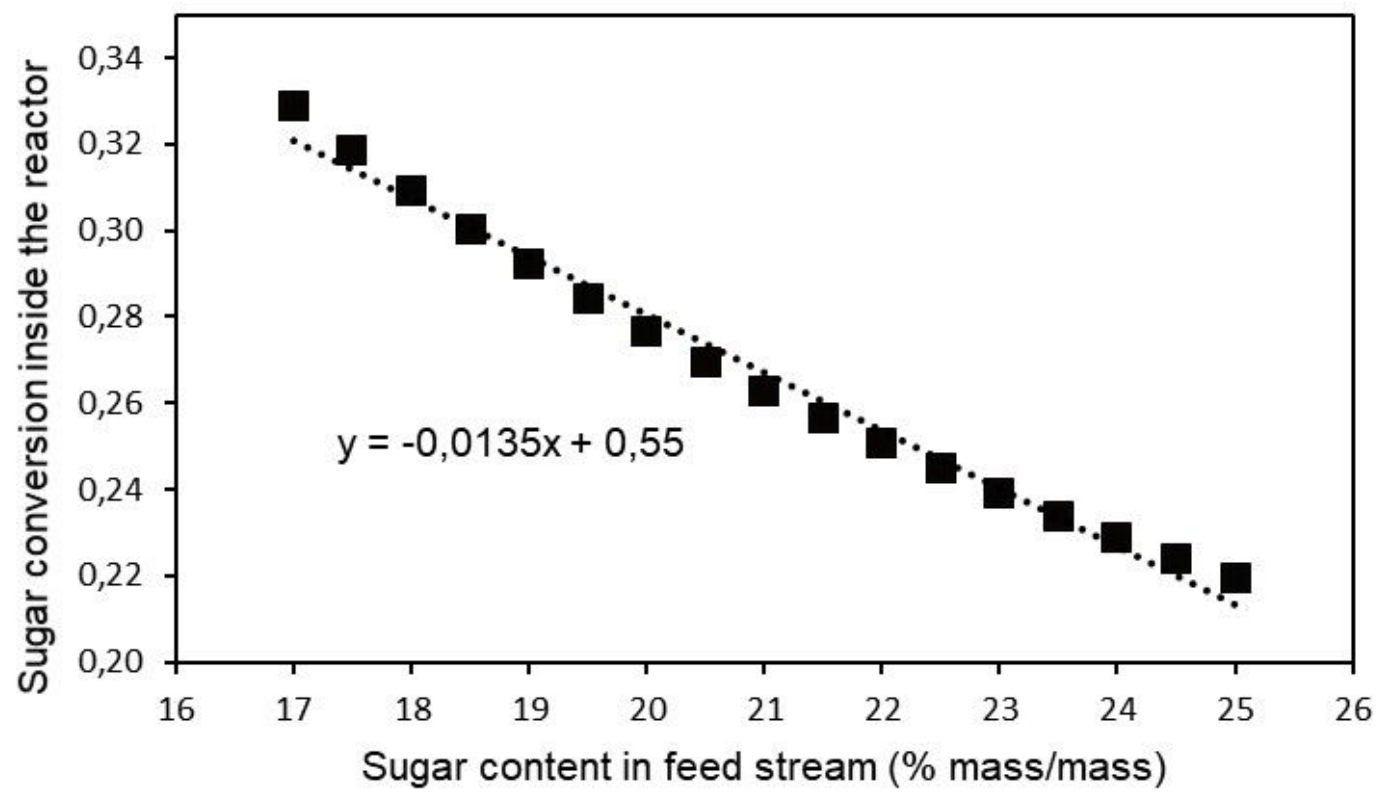

FIGURE 5 - Substrate conversion as function of sugar content in the feed stream. Source: own collection.

It is noticed that sugar conversion in the fermenter falls as the sugar content in the feed rises, in a profile that approaches to the linear. Fonseca et al. (2015) obtained the same behavior in a continuous system similar to the one used in this work. According to Arroyo-López et al. (2009), in most biotechnological processes the substrate will benefit cellular activity at low concentrations and produce inhibitory effects at higher concentrations. According to Najafpour et al. (2003) both substrate and product have inhibitory effects on fermentative processes with $\mathrm{S}$. cerevisiae.

The next simulations aimed to evaluate the effects of temperature on conversion. A parametric study was carried out by varying the temperature at a fixed concentration to evaluate its effects on the maximum specific growth rate $\mu_{\max }$ and 
the concentration of inhibition by product $C_{p}^{*}$. The two variables are modeled byEquations (7) and (8) respectively. Figure 6 shows the behavior obtained:

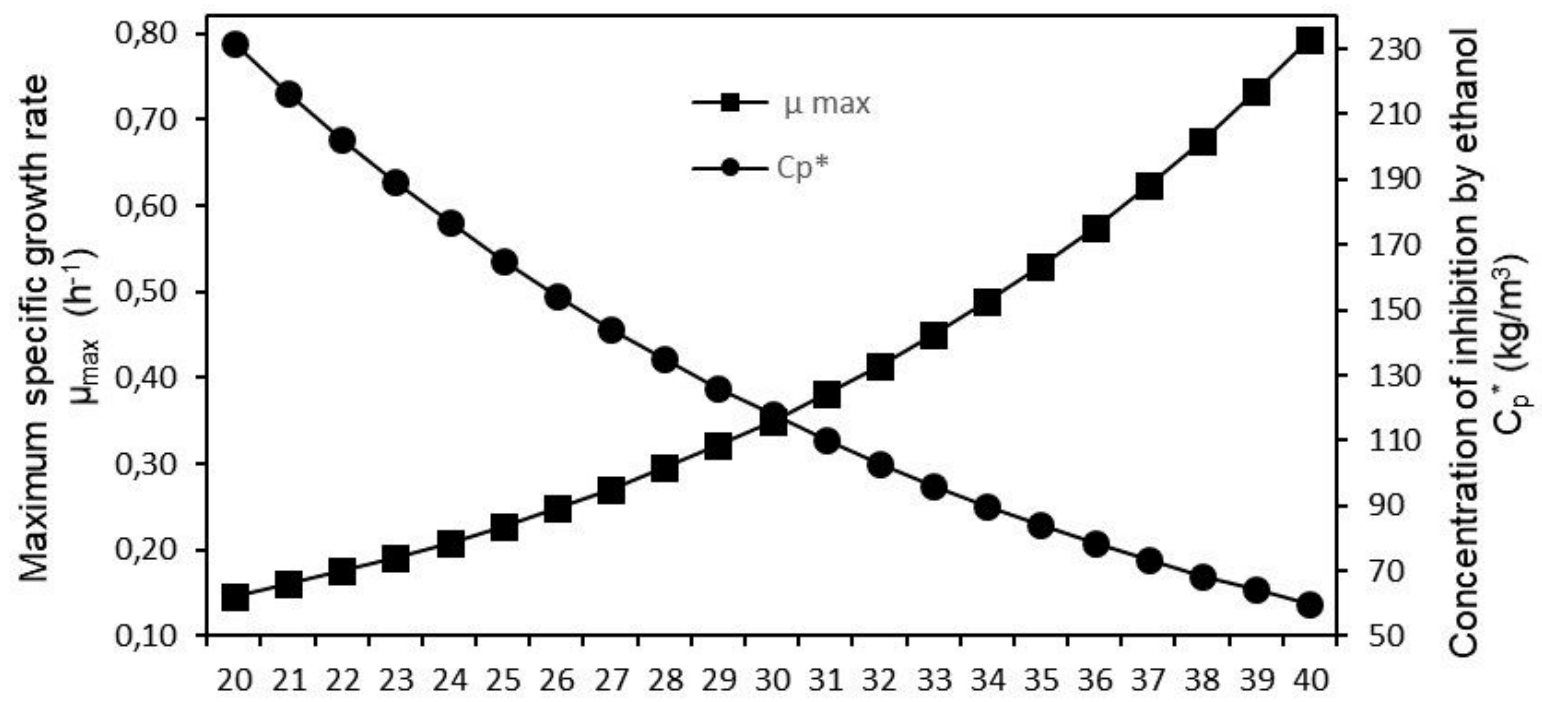

Temperature inside the fermenter $\left({ }^{\circ} \mathrm{C}\right.$ )

FIGURE 6 - Maximum specific growth rate $\left(\mu_{\max }\right)$ and concentration of inhibition by product $\left(C_{p}^{*}\right)$ as function of the temperature of fermentation. Source: own collection.

According to the proposed model the maximum specific growth rate is favored by the increase of temperature. On the other hand, the tolerance of the yeast to ethanol decreases as the temperature rises. Such behaviors are expected, since these are variables modeled by an exponential function whose exponent is negative for $\mu_{\max }$ and positive for $C_{p}^{*}$.

Equation (6) that models the cell growth rate, takes into account both factors $\mu_{\max }$ and $C_{p}^{*}$. Thus, in order to evaluate the behavior of two variables with opposite effects on the cell growth rate, it was necessary to evaluate the sugar conversion in the reactor as a function of the operating temperature, as shown in Figure (7).

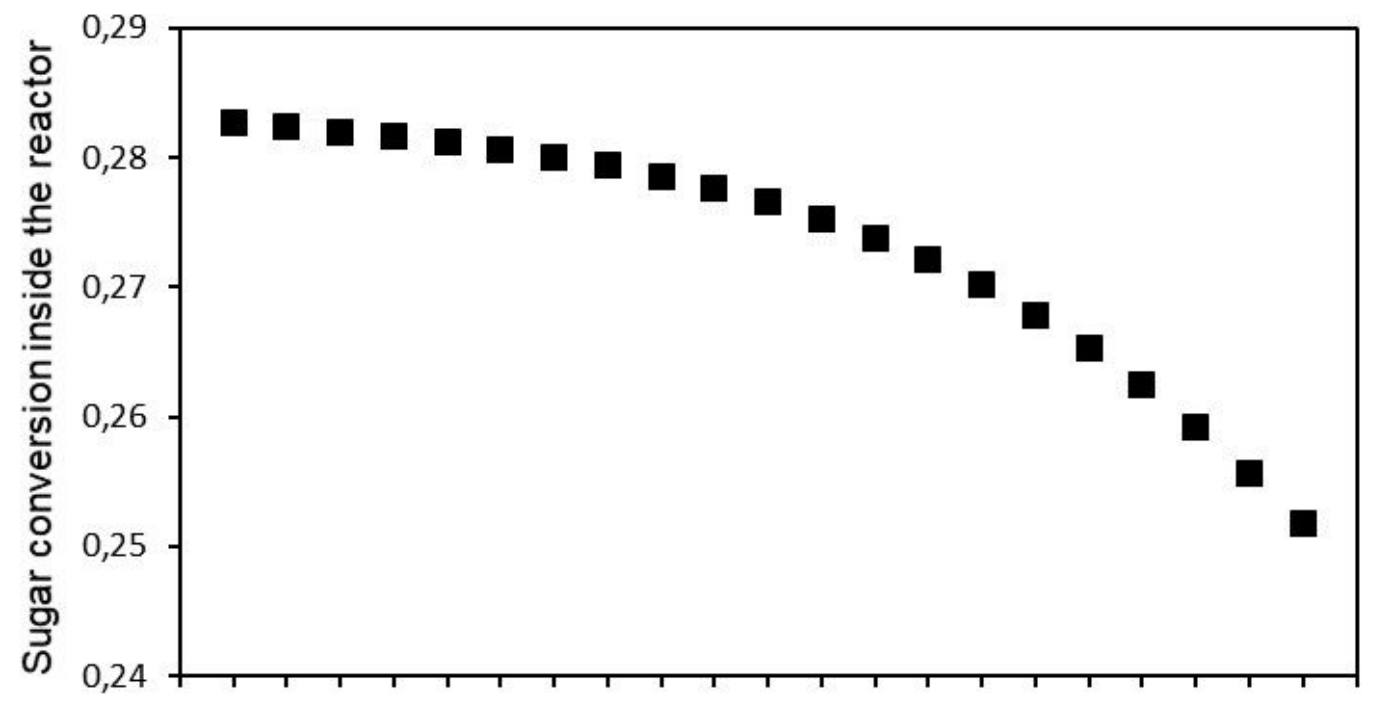

1920212223242526272829303132333435363738394041

Temperature inside the reactor $\left({ }^{\circ} \mathrm{C}\right.$ ) 
FIGURE 7 - Substrate conversion as function of temperature. Source: own collection

It is observed that, in general terms, the increase in temperature disfavours the conversion of sugar into ethanol. The effect is balanced at lower temperatures, but it is accentuated as the temperature increases, becoming quite acute above 30 ${ }^{\circ} \mathrm{C}$. According to Andrietta and Maugeri (1994) the tolerance of S. cerevisiae drops exponentially from $32{ }^{\circ} \mathrm{C}$, which confirms the results obtained in the simulations.

\section{CONCLUSION}

The development of a fermentation module for the COCO Simulator software from its integration with the Scilab software was carried out in this work. The mathematical model applied presented results consistent with those reported in the literature. It provided an ethanol concentration of $54,85 \mathrm{~kg} / \mathrm{m}^{3}$ in the output stream of a continuous single stage reactor. The model presents adequate sensitivity to inhibition factors. The conversion is reduced in a linear pattern with the increase of substrate concentration in the feed stream. The increase in temperature was another negative factor for the conversion. The agent of greater responsibility for the negative effect was the decrease of tolerance to ethanol by the cells, mainly above $30^{\circ} \mathrm{C}$. This system can be improved, and greater conversion can be achieved by the application of a multiple reactor system.

\section{REFERENCES}

Ingenieur Technik, v. 86, n. 7, p. 1052-1064, 2014. Available in: < https://doi ANDRIETTA, S. R.; MAUGERI, F. Optimum design of a continuous fermentation unit of an industrial plant for alcohol production. Advances in bioprocess engineering. Springer, Dordrecht, 1994. p. 47-52. Available in: <https://doi.org/10.1007/978-94017-0641-4_7>. doi: 10.1007/978-94-017-0641-4_7

ARROYO-LÓPEZ, F. N.; QUEROL, A.; BARRIO, E. Application of a substrate inhibition model to estimate the effect of fructose concentration on the growth of diverse Saccharomyces cerevisiae strains. Journal of industrial microbiology \& biotechnology, v. $36, \quad$ n. 5 , p. 663-669, $2009 . \quad$ Available in:<https://doi.org/10.1007/s10295-009-0535-x>. doi:10.1007/s10295-009-0535-x

AZHAR, S. H. M.; ABDULLA, R.; JAMBO, S. A.; MARBAWI, H.; GANSAU, J. A.; FAIK, A. A. M.; RODRIGUES, K. Yeasts in sustainable bioethanol production: a review. Biochemistry and biophysics reports, v. 10, p. 52-61, 2017. Available in: <https://doi.org/10.1016/j.bbrep.2017.03.003>. doi: 10.1016/j.bbrep.2017.03.003

BATEN, J. V.; PONS, M. CAPE-OPEN: Interoperability in Industrial Flowsheet

Simulation Software.

Chemie.org/10.1002/cite.201400009>.

doi: 10.1002/cite.201400009

CHENG, J. Biomass to renewable energy processes. CRC press, 2017. 
DALE, M. C.; CHEN, C.; OKOS, M. R. Cell growth and death rates as factors in the long-term performance, modeling, and design of immobilized cell reactors.

Biotechnology and bioengineering, v. 36, n. 10, p. 983-992, 1990. Available in: <https://doi.org/10.1002/bit.260361003>. doi: 10.1002/bit.260361003

FONSECA, G. C.; COSTA, C. B. B.; CRUZ, A. J. G. Comparing a Dynamic FedBatch and a Continuous Steady-State Simulation of Ethanol Fermentation in a Distillery to a Stoichiometric Conversion Simulation. Brazilian Journal of Chemical Engineering, v. 34, n. 4, p. 1121-1131, 2017. Available in: <http://dx.doi.org/10.1590/0104-6632.20170344s20160155>. doi: 10.1590/01046632.20170344s20160155

FAO. FOOD AND AGRICULTURE ORGANIZATION (FAO). Biofuels. Available in: $<$ http://www.fao.org/3/a-BO103e.pdf>. 2016. Accessed in: 28/10/2018.

GHOSE, T. K.; TYAGI, R. D. Rapid ethanol fermentation of cellulose hydrolysate. II. Product and substrate inhibition and optimization of fermentor design. Biotechnology and Bioengineering, v. 21, n. 8, p. 1401-1420, 1979. Available in: <https://doi.org/10.1002/bit.260210808>. doi: 10.1002/bit.260210808

HENNING, K. Recommendations for implementing the strategic initiative INDUSTRIE 4.0: Securing the future of German manufacturing industry. Final report of the Industrie 4.0 Working Group. Forschungsunion, 2013.

JESCHKE, S. S.; BRECHER, C.; MEISEN, T.; ÖZDEMIR, D.; ESCHERT, T. Industrial internet of things and cyber manufacturing systems. Industrial Internet of Things. Springer, Cham, 2017. p. 3-19. Available in: <https://doi.org/10.1007/978-3319-42559-7_1>. doi: 10.1007/978-3-319-42559-7_1

KIDA, K.; YAMADAKI, M.; ASANO, S. I.; NAKATA, T.; SONODA, Y. The effect of aeration on stability of continuous ethanol fermentation by a flocculating yeast. Journal of fermentation and bioengineering, v. 68, n. 2, p. 107-111, 1989. Available in: < https://doi.org/10.1016/0922-338X(89)90057-3>. doi: 10.1016/0922338X(89)90057-3.

LEE, J. M.; POLLARD, J. F.; COULMAN, G. A. Ethanol fermentation with cell recycling: computer simulation. Biotechnology and bioengineering, v. 25, n. 2, p. 497-511, 1983. Available in: < https://doi.org/10.1002/bit.260250215>. doi: 10.1002/bit.260250215

MAYNARD, A. D. Navigating the fourth industrial revolution. Nature nanotechnology, v. $10, \quad$ n. 12, p. 1005, 2015. Available in: <https://doi.org/10.1038/nnano.2015.286>. doi: 10.1038/nnano.2015.286

NAJAFPOUR, G.; YOUNESI, H.; ISMAIL, K.; S.; KU. Ethanol fermentation in an immobilized cell reactor using Saccharomyces cerevisiae. Bioresource technology, v. $92, \quad$ n. $3, \quad$ p. 251-260, $2004 . \quad$ Available 
in:<https://doi.org/10.1016/j.biortech.2003.09.009>.

doi:10.1016/j.biortech.2003.09.009

PALACIOS-BERECHE, R.; ENSINAS, A. V.; MODESTO, M.; NEBRA, S. A. Doubleeffect distillation and thermal integration applied to the ethanol production process. Energy, v. 82, p. 512-523, 2015. Available in: $<$ https://doi.org/10.1016/j.energy.2015.01.062>. doi: 10.1016/j.energy.2015.01.062.

QIAN, F.; ZHONG, W.; DU, W. Fundamental theories and key technologies for smart and optimal manufacturing in the process industry. Engineering, v. 3, n. 2, p. 154160, 2017. Available in: <http://dx.doi.org/10.1016/J.ENG.2017.02.011>. doi: 10.1016/J.ENG.2017.02.011.

ROSEN, R.; VON WICHERT, G.; LO, G.; BETTENHAUSEN, K. D. About the importance of autonomy and digital twins for the future of manufacturing. IFACPapersOnLine, v. 48, n. 3, p. 567-572, 2015. Available in: < https://doi.org/10.1016/j.ifacol.2015.06.141>. doi: 10.1016/j.ifacol.2015.06.141.

RÜBMANN, M.; LORENZ, M.; GERBERT, P.; WALDNER, M.; JUSTUS, J.; ENGEL, P.; HARNISCH, M. Industry 4.0: The future of productivity and growth in manufacturing industries. Boston Consulting Group, v. 9, 2015.

SCILAB. What is Scilab. Available in <http://scilab.io/products/scilab/>. Accessed in: 03/11/2018

STATE COUNCIL OF THE PEOPLE'S REPUBLIC OF CHINA. Made in China 2025 strategy. Beijing: State Council of the People's Republic of China. 2015. Available in: <http://www.gov.cn/zhengce/content/2015-05/19/content_9784.htm>. Accessed in: 25/10/2018.

TAYLOR, F.; KURANTZ, M. J. GOLDBERG, N., \& CRAIG, J. C. Continuous fermentation and stripping of ethanol. Biotechnology progress, v. 11, n. 6, p. 693698, $1995 . \quad$ Available in: $<$ https://pubs.acs.org/doi/abs/10.1021/bp00036a014?journalCode=bipret>. $\quad$ DOI: 10.1021/bp00036a014.

THE OFFICE OF SCIENCE AND TECHNOLOGY POLICY. Strategy for American leadership in advanced manufacturing. OSTP, 2018. Available in: $<$ https://www.whitehouse.gov/wp-content/uploads/2018/10/Advanced-ManufacturingStrategic-Plan-2018.pdf>. Accessed in: 23/10/2018.

VAN BATEN, J.; PONS, M. CAPE-OPEN: Interoperability in Industrial Flowsheet

Simulation Software. Chemie Ingenieur Technik, v. 86, n. 7, p. 1052-1064, 2014. Available in: < https://doi.org/10.1002/cite.201400009>. doi: 10.1002/cite.201400009.

WOOLEY, R. J.; PUTSCHE, V. Development of an ASPEN PLUS physical property database for biofuels components. NREL, 1996. Available in: <https://www.nrel.gov/docs/legosti/old/20685.pdf>. Accessed in: 07/11/2018.

ZABED, H.; SAHU, J. N.; SUELY, A.; BOYCE, A. N.; FARUQ, G. Bioethanol production from renewable sources: Current perspectives and technological ENCICLOPÉDIA BIOSFERA, Centro Científico Conhecer - Goiânia, v.16 n.29; p. 2325 
progress. Renewable and Sustainable Energy Reviews, v. 71, p. 475-501, 2017. Available in: <http://dx.doi.org/10.1016/j.rser.2016.12.076>. doi: 10.1016/j.rser.2016.12.076. 